bronchial irritability syndrome be used as operational criteria for the diagnosis of asthma but believed not only that this was premature but that to do something so potentially controversial might obscure the message we primarily wished to convey. Because studies were planned and are now in progress to explore the value of the bronchial irritability syndrome in predicting potential responsiveness to treatment with sodium cromoglycate and steroids we preferred to await these further data.

Faculty of Medicine,

J L HOWEL Southampton General Hospital,

Southampton SO9 4XY

1 Mortagy AK, Howell LBL, Waters WR. Respiratory symptom and bronchial reactivity: identification of a syndrome and is relation to asthma. BrMed J 1986;293:525-9.

2 Dales RE, Ernest P, Hanley JA, et al. Prediction of airway reactivity from responses to a standardised respiratory symptom questionnaire. Am Rev Respir Dis 1987;135:817-21.

\section{Clinical Algorithms: Infertility}

SIR,-In her algorithm on infertility (4 April, p 887) Mrs T R Varma suggested that high dose steroid treatment might be considered for immunological infertility in men. This was enthusiastically supported and advocated by Dr J Houghton (9 May, p 1229), but we think that this approach to treatment cannot be left unchallenged.

Reports of a beneficial effect of short term high dose prednisolone treatment on fertility have been based on the results of small, uncontrolled studies in men with antisperm antibodies in the serum. ${ }^{1-4}$ Locally secreted antisperm antibodies, however, which probably have more relevance to sperm function and fertility, were not assessed in these studies. Patients were not categorised according to isotype of the antibodies, and pregnancy rates were not related to antibody titre or duration of treatment. In a small, also uncontrolled, study of similar treatment in men with antisperm antibodies in the semen Hendry et al reported a crude pregnancy rate of $31 \%$, two of the pregnancies occurring in the absence of any reduction in antibody titre. ${ }^{5}$

High dose corticosteroid treatment carries the risk of serious side effects. Haemetemesis and avascular necrosis of the femoral head may occur in up to $6 \%$ of treated men, and less severe side effects of hip pain, dyspepsia, aggressive behaviour, and visual disturbance occur in a further $16-27 \% .{ }^{+5} \mathrm{We}$ therefore do not consider that such a potentially hazardous form of treatment should be embarked on without the risks being clearly explained to recipients, especially when there is little objective evidence to support its effectiveness.

We believe that until large, controlled studies have established the efficacy of steroid treatmen for immunological infertility in men the risk of these severe and debilitating side effects cannot be justified.

Max Elstein C A Vaughan Williams S M SHALE

Department of Obstetrics and Gynaecology,

University Hospital of South Manchester,

Manchester M20 8LR

1 Hendry WF, Morgan H, Stedronska. The clinical significance of antisperm antibodies in male infertility. Brf Urol 1977;9:757.

2 Shulman S, Harlin B, Davis P, Reyniak JV. Immune infertility and new approaches to treatment. Fertil Steril 1978;29:309.

3 Dondero F, Isidori A, Lenzi A, et al. Treatment and follow up of patients with infertility due to spermagglutinins. Feril Steri 1979;31:48-51.

4 Jones WR. The treatment of immunologically conditioned infertility. In: Harrison RF, Bonnar J, Thompson W, eds. Proceedings of the XIth world congress on fertility and sterility. Dublin, fune 1983. Lancaster: MTP Press, 1983.
5 Hendry WF, Stedronska J, Parslow J, Hughes L. The results of intermittent high dose steroid therapy for male infertility due to antisperm antibodies. Fertil Steril 1981;38:591.

Irritable bowel syndrome as a cause of chronic pain in women attending a gynaecological clinic

SIR,-I am grateful to Dr Cynthia Farquhar and colleagues for their comments on my paper ( 9 May, p 1228) but am surprised at their reluctance to accept the irritable bowel syndrome as a common cause of chronic pain in women.

Firstly, the questionnaire used in our study is widely accepted as a useful aid to the diagnosis of the irritable bowel syndrome and is an accurate means of taking an adequate history. Furthermore, physical signs recognised as markers of an irritable bowel were sought and found in over $70 \%$ of our patients.

Secondly, Dr Farquhar and coworkers doubt that dyspareunia is a manifestation of the irritable bowel syndrome, yet this has been adequately documented by Fielding, ${ }^{12}$ and Whorwell $e^{2} a^{3}$ have similarly shown that dyspareunia is significantly more common than other gynaecological symptoms in patients with the irritable bowel syndrome.

Though ours was a small study, Heaton has argued that the irritable bowel syndrome is likely to be a common cause of chronic pain in women referred to a gynaecologist. ${ }^{4}$ No previous study of chronic pelvic pain in women has given details of how the irritable bowel syndrome was excluded as a cause of pain, and the low incidence at St Mary's Hospital may reflect the pattern of referrals.

Even if $60 \%$ of the patients in my study now have an explanation for their pain many do not, and there is room for a lot more work.

Patrick Hogston

Department of Human Reproduction and

Obstetrics,

Princess Anne Hospital,

Southampton SO9 4HA

Fielding JF. A year in outpatients with the irritable bowe syndrome. Ir F Med Sci 1977; 146:162-6.

2 Keiling PWN, Fielding JF. The irritable bowel syndrome fournal of the International College of Physicians and Surgeon 1975;4:91-4.

Whorwell PJ, McCallom M, Creed FH, Roberts CT. Noncolonic features of irritable bowel syndrome. Gut 1986;27: 37-40.

4 Heaton KW. Pelvic pain in women. Br Med f 1986;293:1504.

\section{Unemployment and mortality}

SIR,-Mr K A Moser and colleagues (10 January, p 86) provide the first evidence of high mortality among men seeking work in the early 1980s in Britain. Similar results are suggested by a longitudinal study that followed more than one million people resident in Turin, Italy, at the time of the general census in October 1981. The sources of the data and the methods used, as well as the main findings regarding mortality up to 1985, are being summarised in a report, which will be available at the end of 1987.

The study included 13462 men, aged 15-59, who, having lost their job, were seeking a new one in the week before the 1981 census $(4 \%$ of all men of working age). In the period 1981-5 these men experienced a higher mortality than expected from death rates in all the men in the study (standardised mortality ratio $=202,95 \%$ confidence limits 179 to 227). The excess was similar in different age groups (217 and 195, respectively, before and after age 45 at death). The distribution of some potential confounders (tenure, education, region of birth, and marital state) differed between those seeking work and all men of working age. Standardisation for these characteristics, however, had little effect on mortality (table I).

According to the information on employment state in 1976, provided by the same census, overall mortality among men seeking work in both 1976 and 1981 was even higher (table II). Mortality by cause of death showed significant excesses for all major categories (table III); deaths from both suicide and murder were overrepresented (standardised mortality ratios $=285$, based on 15 suicides, and 677, based on nine murders).

Contrary to the findings in the Office of Population Censuses and Surveys' longitudinal study, our data are partially compatible with the possibility that men who were unemployed because of ill health had classified themselves as seeking work. Indeed, analysis by calendar year shows an excess mortality among the unemployed since the beginning of follow up, even if a definite unhealthy selection effect is evident only in the category of not active men, which includes the disabled (table IV). The overall mortality among unemployed, however, is still in excess after the exclusion of people receiving a disability pension (table $\mathrm{V}$ ).

In conclusion, our preliminary results support

TABLE I-Mortality 1981-5 for all men and men seeking work in 1981 aged $15-59$ by tenure

\begin{tabular}{|c|c|c|c|}
\hline \multirow[b]{2}{*}{ Tenure } & \multirow{2}{*}{$\begin{array}{c}\text { Standardised } \\
\text { mortality ratio } \\
\text { (observed No) } \\
\text { for all men }\end{array}$} & \multicolumn{2}{|c|}{ Men seeking work in 1981} \\
\hline & & $\begin{array}{l}\text { Standardised } \\
\text { mortality ratic } \\
\text { (observed No) }\end{array}$ & $\begin{array}{l}\text { Mortality ratio } \\
\text { standardised } \\
\text { by tenure }\end{array}$ \\
\hline \multirow{3}{*}{$\begin{array}{l}\text { Owner } \\
\text { Tenant } \\
\text { Inadequately } \\
\text { described }\end{array}$} & $84(1855)$ & $219(77$ & 25 \\
\hline & $109(2936)$ & $188(181)$ & 173 \\
\hline & $141(340)$ & $291(26)$ & 201 \\
\hline Total & $100(5131)$ & $202(284)$ & 193 \\
\hline
\end{tabular}

TABLE II-Mortality in 1981-5 for men aged 15-59 in 1981 according to employment state in 1976 and 1981

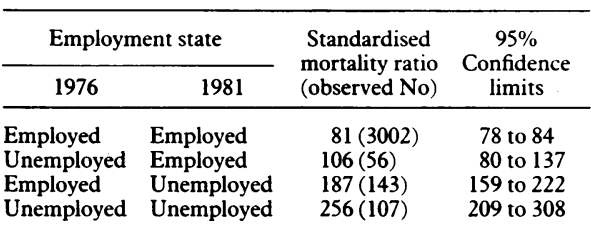

TABLE III-Mortality in 1981-5 of men seeking work in 1981 aged $15-59$ by cause of death

\begin{tabular}{|c|c|c|}
\hline Cause of death & $\begin{array}{l}\text { Standardised } \\
\text { mortality ratio } \\
\text { (observed No) }\end{array}$ & $\begin{array}{c}95 \% \\
\text { Confidence } \\
\text { limits }\end{array}$ \\
\hline Malignant neoplasms & $175(78)$ & 137 to 216 \\
\hline Circulatory diseases & $168(66)$ & 125 to 205 \\
\hline Respiratory diseases & $170(6)$ & 63 to 373 \\
\hline Digestive diseases & $316(38)$ & 224 to 435 \\
\hline $\begin{array}{l}\text { Accidents, poisonings, } \\
\text { and violence } \\
\text { Other causes }\end{array}$ & $\begin{array}{l}245(61) \\
220(35)\end{array}$ & $\begin{array}{l}187 \text { to } 313 \\
153 \text { to } 306\end{array}$ \\
\hline
\end{tabular}

TABLE IV-Standardised mortality ratio (observed No) in 1981-5 for men aged 15-59 in 1981 by economic position and year of death

\begin{tabular}{lcccc}
\hline & \multicolumn{4}{c}{ Economic position } \\
\cline { 2 - 5 } $\begin{array}{l}\text { Year of } \\
\text { death }\end{array}$ & Employed & Unemployed & Retired & Not active \\
\hline 1981 & $79(128)$ & $88(5)$ & $146(46)$ & $376(16)$ \\
1982 & $81(731)$ & $158(52)$ & $155(267)$ & $349(74)$ \\
1983 & $80(799)$ & $222(79)$ & $160(305)$ & $283(65)$ \\
1984 & $86(804)$ & $186(62)$ & $132(252)$ & $246(54)$ \\
1985 & $84(776)$ & $259(86)$ & $137(251)$ & $207(44)$ \\
\hline
\end{tabular}


TABLE V-Standardised mortality ratio (observed No) in 1981-5 for all men and men seeking work in 1981 aged 15-59 according to possession of a disability pension

\begin{tabular}{|c|c|c|}
\hline Disability pension & All men & $\begin{array}{c}\text { Men } \\
\text { seeking work }\end{array}$ \\
\hline $\begin{array}{l}\text { Yes } \\
\text { No }\end{array}$ & $\begin{array}{c}191(660) \\
93(4471)\end{array}$ & $\begin{array}{l}278(24) \\
197(260)\end{array}$ \\
\hline
\end{tabular}

the first findings from the Office of Population Censuses and Surveys' longitudinal study that unemployment in the early 1980 s is associated with increased mortality.

GUISEPPE COSTA

Unità Sanitaria Locale 1-23,

Area di Epidemiologia,

10123 Turin,

Italy

Nereo SEgnaN

What are health authorities doing about the
health problems caused by unemployment?

SIR,-With regard to the article by Ms Christiane Harris and Dr Richard Smith (25 April, p 1076), health authorities can be active in the primary prevention of the ill health caused by unemployment. ${ }^{12}$ A national network of product development agencies has been formed by over 30 groups involved in "alternative technology"-developing products for which there is an identified social need, using the skills of workers who are unemployed or working in armaments manufacture, and locally available resources. Ideas for products for which local people have identified a need are developed with groups of workers with the necessary skills.

Technical support to existing businesses further enhances local employment prospects. Many of these agencies are based in polytechnics and use student project work-in engineering, design, computing, management, and marketing-to develop products. Among these agencies are the Sheffield centre for product development and technological resources at Sheffield City Polytechnic and the unit for the development of alternative products at Coventry (Lanchester) Polytechnic. The economic development units of some councils and cooperative development agencies are also participating. Among the products that have been developed in this way are the Monseco advanced dehumidifier to combat dampness; Audiocalc, the speaking spreadsheet for blind people; telescopic implants for children with osteogenesis imperfecta (by the Sheffield centre and Sheffield Employment Department); the Covloc display board system; the BEA lift bath aid for handicapped children; a ventilator alarm; a domestic ventilator for patients with neurological breathing problems; and electric and hybrid powered (combined petrol and electric) vehicles (by the unit at Coventry)

Health services can contribute actively to local employment prospects by establishing links with local authority economic development units, higher education centre economic or engineering departments, and alternative technology agencies. Health workers can identify needs for products for the sick or handicapped, they can help to evaluate new health care products, and they can advocate the purchase of products developed in this way. A special health authority for National Health Service procurement would be able to buy products built in this country and state requirements for products that were needed by the National Health Service and could be made here.

Intermediate, appropriate, or development technology agencies work mainly on projects with the developing world. These agencies do not export products that are disabling to a developing economy but provide skills, designs, or tools that workers in developing countries can use. Appropriate Technology Design and Development of Moreton-in-Marsh, Gloucestershire, has produced designs for metal rolling and pipe bending machines that have been built in African countries to cannibalise scrap metal for farming equipment, cooking utensils, and even tricycles for polio victims. The unit at Coventry has designed a small scale smelter and a small scale brick maker, both of which use old engine oil, a plentiful commodity in developing countries. In addition, a Coventry firm is building a containerised toolshop to the specifications of Indian farm workers.

Arms conversion-the use of military technology for peaceful purposes - is another element of the work of some of these agencies. It is widely acknowledged that military industries provide fewer jobs for a given investment; they are major consumers of raw materials, energy, and research funds and thus contribute to high inflation rates, high interest rates, and poor potential for investment in socially useful, peaceful production. ${ }^{12}$

Alternative technology embraces the principles of "Health for all": healthy work practices, community participation, democracy, and local initiatives leading to international cooperation and to "peace which is more than the absence of war."

Sandwell Health Authority,

JOHN MIDDLETON

West Bromwich,

West Midlands B70 9LD

\section{Unit for the Development of \\ Alternative Products, \\ Coventry Polytechnic, \\ Coventry CV1 5FB}

Department of Employment and

Economic Development,

Sheffield City Council

Sheffield S1 $2 \mathrm{HN}$

1 United Nations Expert Committee on Development and Disarmament. Report. New York: United Nations Organisation, arma

2 Middleton JD, Routley J, Lowe B. Swords to ploughshares: improving the world's health. Journal of Medicine and War (in press)

\section{Promoting prevention in primary care}

SIR,-The idea of providing low cost support for primary health care teams to introduce opportunistic screening into their practices is attractive, and we would like to congratulate Ms Elaine Fullard and colleagues on their evident success in promoting collaboration between those responsible for primary care, local authorities, and family practitioner committees to implement it (25 April, p 1080).

Experiments in introducing preventive medicine into primary care are much needed, and it is good to see audit of the process built into the project and to know that a study of outcome is planned. We are not, however, convinced that the study design allows the conclusion that improvement in recording of cardiovascular risk factors in the three selected intervention practices was due to the "facilitator package" offered. Anyone who has tried to define practice characteristics to allow matching of case controls knows how limited the possibilities are, but the variables used in the study by Ms Fullard and coworkers ignore perhaps the most important factors affecting uptake of a new preventive service in general practice. These include the differing beliefs and attitudes of those working in each practice, their working relationships, and the resulting readiness of the team for change.

In the design used in the study the three intervention practices were selected on the basis of their willingness to change, while the comparison practices were not. Thus the design does not control for the possibility of systematic differences in enthusiasm between staff in the intervention and comparison practices. Moreover, the design does not allow us to distinguish between the effect of the continuing support of a facilitator and the effect of involvement in periodic audit as the comparison practices were offered only retrospective audit.

The ideal randomised controlled trial is hard to achieve with whole practices because of the numbers and cost concerned. We believe that smaller studies evaluating the potential of a range of approaches to improving prevention and surveillance in general practice are justified; these should, however, randomise practices willing to change between experimental and control groups. Only in this way can we begin to distinguish the effects of the intervention from the effects of enthusiasm.

ANN-LOUISE KINMONTH GEORGE FREEMAN NICKI WATKINS JOHN BAIN

Faculty of Medicine,

University of Southampton,

Southampton SO1 6ST

Subcutaneous calcium heparin versus intravenous sodium heparin in treatment of established acute deep vein thrombosis of the legs

SIR,-Mr M G Walker and colleagues (9 May, p 1189) conclude from their study of the treatment of acute deep vein thrombosis that "subcutaneous calcium heparin was more effective in helping lyse existing thrombus and preventing its propagation than intravenous sodium heparin."

It seems to me, however, that what they in fact showed was that larger doses of subcutaneous heparin (mean (SD) 29375 (8354) IU) established greater degrees of anticoagulation (according to kaolin cephalin clotting time estimations) and resulted in greater lysis of clot than smaller doses of intravenous heparin (mean (SD) 24384 (12 402) IU) and lower levels of anticoagulation. Their results are, therefore, not at variance with those of Hull et al, who also showed that lower doses of heparin and levels of anticoagulation (particularly in the first 24 hours) were associated with higher rates of recurrence of proximal vein thrombosis. The main difference, however, was that in the study by Hull et al the lower doses were given subcutaneously and the higher intravenously.

The difference in the dose of heparin administered in the two treatment groups in the study by $\mathrm{Mr}$ Walker and coworkers surely renders invalid any conclusions about the relative efficacy of the drug given by these different routes.

\section{NEIL SCOLDING}

\section{University College of Medicine,}

Cardiff CF4 4XN

1 Hull RD, Raskob GE, Hirsch J, et al. Continuous intravenous heparin compared with intermittent subcutaneous heparin in the initial treatment of proximal vein thrombosis. N Engl f Med 1986;315:1109-4.

AUTHORS' REPLY,-In reply to Dr Scolding's comments on our paper we should like to point out the following facts.

Firstly, in our discussion we drew attention to the fact that patients in the subcutaneous calcium heparin group received on average a higher dose of heparin and therefore had a higher level of anticoagulation than the intravenous group. We suggested this as one of the possible reasons for the 